\title{
Competition Policy Implications of Electronic Business-to-Business Marketplaces: Issues for Marketers
}

by

\author{
Andrew Pressey
}

Norwich Business School and the ESRC Centre for Competition

Policy, University of East Anglia

\&

John Ashton

Norwich Business School and the ESRC Centre for Competition

Policy, University of East Anglia

\section{CCP Working Paper 07-15}

Abstract: Electronic marketplaces (e-marketplaces) allow networks of buyers and sellers to conduct business online and to exchange information more efficiently using Internet technology. Despite the benefits that e-marketplaces potentially afford firms, concerns have been raised that these markets may damage competition. This study considers the antitrust or competition legislation related to e-marketplaces and examines the possible competition concerns they raise. Potentially anticompetitive features of e-marketplaces are examined and guidance for firm conduct when creating or participating in an e-marketplace is offered.

June 2007

JEL Classification Codes: M31, K21, L42

Keywords: Electronic marketplaces, antitrust, policy

\section{Acknowledgements:}

The usual disclaimer applies. The support of the Economic and Social Research Council is also gratefully acknowledged.

\section{Contact details:}

Andrew D. Pressey, Norwich Business School and the ESRC Centre for Competition Policy, University of East Anglia, Norwich, NR4 7TJ.

a.pressey@uea.ac.uk 


\section{Introduction}

Internet technology has significantly changed the ways in which firms collaborate and compete. One such development as to how firms cooperate within business-to-business markets is provided by electronic marketplaces (e-marketplaces). E-marketplaces - sometimes referred to as e-hubs, businesst-to-business (B2B), or online exchanges - allow networks of buyers and sellers to conduct business online and to exchange information related to the terms and conditions of trade (Varadarajan and Yadav, 2002; de Boer et al. 2002). This study provides a discussion of the competition policy implications of this increasingly important form of commerce.

By trading through portals such as 'SupplyOn' (an online marketplace for tierone and -two automotive suppliers) firms and industries can potentially benefit from reduced buyer/supplier search costs, improved communications between buyers and sellers and the improved flow of goods through the supply chain. During the 1990s, e-marketplaces grew rapidly from a handful of websites in sectors such as chemicals and metals to some 750 e-marketplaces in 2000 (Brunelli, 1999; The Economist, 2000). It is currently estimated that in excess of 1000 e-marketplaces are in operation (eMarket Services, 2007), having now gained broad acceptance in most industries (Howard et al. 2005). For example, Volkswagen Group's e-marketplace 'VWgroupsupply.com' handles $90 \%$ of their global purchasing volume, including all automotive parts, indirect materials and components amounting to US $\$ 77$ billion annually - more than $70 \%$ of the Group's annual revenue.

Despite the benefits of trading via e-marketplaces, concerns persist that the characteristics of some electronic marketplaces might damage competition and consequently be construed as anticompetitive (Fontenot and Hyman, 2004). Discussion of this issue is important as while several articles have adopted a legal perspective when discussing e-marketplaces (Dajani, 2001; Bailey, 2001; Sterling, 2001; Horton and Schmitz, 2002; Laflamme and Biggio, 2001), limited attention has been dedicated to comprehending the potential competition policy threats e-marketplaces pose for the industrial marketer (Fontenot and Hyman, 2004; Lichtenthal and Eliaz, 2003). 
Understanding the competition policy issues that e-marketplaces pose goes beyond assisting industrial marketers in avoiding potential legal pitfalls. Identifying what constitutes a 'competitive' exchange is increasingly important as e-marketplaces are now a common platform for many B2B transactions. Subsequently, addressing potential competition issues ensures a level playing field for all participants and alleviates many of the concerns of parties (such as suppliers) participating in e-marketplaces. In general, competition law is important for marketers to comprehend when new technologies afford firms greater opportunities to collaborate.

Within this study, after a brief review of the definition, benefits and perceived drawbacks of e-marketplaces, the potentially anti-competitive concerns are identified and linked with practical remedies. As US competition or antitrust law governing B2B e-marketplaces falls under the Sherman Act and Clayton Act, our assessment is based on the Federal Trade Commission (FTC) and the Department of Justice (DOJ) interpretation of US antitrust law. This jurisdiction is adopted for this assessment due to the relatively developed regulatory discussion of competition policy concerns with e-marketplaces in the USA.

\section{Business-to-business electronic marketplaces - a background}

Definition of e-marketplaces

While research regarding e-marketplaces is still at a formative stage, considerable interest concerning their role in supply chain management has been generated (e.g. Howard et al. 2005; Ordanini et al. 2004; Eng, 2004; Skjøtt-Larsen et al. 2003; Lancioni et al. 2003a, Lancioni et al. 2003b; Goldsby and Eckert, 2003; Presutti, 2003; Garcia-Dastugue and Lambert, 2003; Sharma, 2002; Dou and Chou, 2002; Deeter-Schmelz and Norman Kennedy, 2002). In particular, e-marketplaces have gained widespread acceptance across numerous business-to-business markets (Eng, 2004) as a means to allow networks of buyers and sellers to conduct business online and to exchange information more efficiently (Varadarajan and Yadav, 2002; IBM 
et al, 2000). E-marketplaces provide firms with a common platform for interactive transactions and collaboration between buyers and sellers.

E-marketplaces are usually sponsored by one party or a small number of parties (referred to as 'market makers') with the sole purpose of drawing together buyers and sellers in a particular sector (Grewal et al. 2001; Klein and Quelch, 1997). For example, the web-based trading systems 'Converge' - a global marketplace for semiconductor and computer peripheral industries - has 6,500 trading partners in 139 countries ('www.converge.com'), or 'RF Globalnet' - a marketplace for microwave subsystems and components - has in excess of 3,000 suppliers listed ('www.rfglobalnet.com').

Ownership structure of e-marketplaces varies and includes private ownership (e.g. 'VWgroupsupply.com' operated by the Volkswagen Group), third-party ownership through a number of non-competing/independent firms (e.g. 'SupplyOn' operated by a number of German automotive suppliers), and consortia between competing firms sponsoring an exchange (e.g. the automotive marketplace 'Covisint' in its original guise).

Figure 1: Benefits of e-marketplace participation

\begin{tabular}{|c|c|}
\hline Proposed benefit & Author(s) \\
\hline $\begin{array}{l}\text { Collaboration between buyers and sellers including } \\
\text { product design and supply chain management. }\end{array}$ & $\begin{array}{l}\text { Howard et al. (2005); } \\
\text { IBM et al. (2000); } \\
\text { Kalyanam and Mclntyre } \\
\text { (2002); FTC (2000). }\end{array}$ \\
\hline $\begin{array}{l}\text { Online real time functionality (including online auctions } \\
\text { and negotiations). }\end{array}$ & $\begin{array}{l}\text { McKenna (1997); IBM et } \\
\text { al. (2000). }\end{array}$ \\
\hline $\begin{array}{c}\text { Aggregated industry information (including product } \\
\text { information) and industry news. }\end{array}$ & IBM et al. (2000). \\
\hline Facilitation of relationship development and cooperation. & $\begin{array}{c}\text { Lancastre and Lages } \\
\text { (2002); Barratt and } \\
\text { Rosdahl (2002); FTC } \\
\text { (2000). }\end{array}$ \\
\hline $\begin{array}{c}\text { Reduced buyer/supplier search costs; better informed } \\
\text { decision-making. }\end{array}$ & $\begin{array}{l}\text { Bakos (1997); Bakos } \\
\text { (1991); FTC (2000). }\end{array}$ \\
\hline $\begin{array}{l}\text { Improved communications and information sharing } \\
\text { between buyers and sellers. }\end{array}$ & Eng (2004). \\
\hline $\begin{array}{l}\text { More efficient movement of goods through the supply } \\
\text { chain. }\end{array}$ & Eng (2004); FTC (2000). \\
\hline $\begin{array}{c}\text { Reduce risk by quickly identifying new suppliers if } \\
\text { problems arise. }\end{array}$ & de Boer et al. (2002). \\
\hline Creation of a level playing field for both small and large & Eng (2004). \\
\hline
\end{tabular}




\begin{tabular}{c|c}
\hline firms. & \\
\hline New market creation; joint purchasing efficiencies; & FTC (2000). \\
increased efficiency through systems integration; & \\
assisting comparison between suppliers and their & \\
offerings; providing a 'middleman' function that otherwise & \\
lacks credibility; reduced maverick & \\
purchasing/unauthorised spending and facilitating online & \\
auctions; reduced administrative costs and errors; \\
reduced 'exception handling'; managing international \\
sales.
\end{tabular}

\section{Benefits of e-marketplaces}

Potential cost savings are the most obvious benefit of e-marketplaces. The average cost of a face-to-face sales call in the chemicals and pharmaceuticals sector is estimated to be $\$ 575$, whereas the same transaction is thought to cost around $\$ 10$ through an e-marketplace. Similarly, for small- to mediumsized enterprises (SMEs), a typical 'paper' transaction/purchase order that might cost $\$ 100$ could potentially be reduced to $\$ 10$ conducted via an emarketplace (FTC, 2000). As well as financial rewards, many other advantages of e-marketplaces have been widely touted; a selection of these benefits is summarised in Figure 1. In summary, e-marketplaces offer firms a forum to potentially collaborate more effectively and efficiently than previously (Skjøtt-Larsen et al. 2003; Eng, 2004).

\section{Potential drawbacks to e-marketplace participation}

Although firms can gain considerably from e-marketplace participation, potential drawbacks exist. Such problems include technological compatibility, perceived risks, trust concerns, attracting market participants, legal issues and some initial supplier resistance. Many legacy systems or a low level of business automation are not well matched to the technological demands of emarketplaces (Eng, 2004; FTC, 2000). Furthermore, many managers perceive moving from an established distribution channel to an electronic market to be a high risk option (Kaplan and Sawhney, 2000). Within many firms trust concerns also arise if non-standard items are traded (Axelsson and Wynstra, 2002). Similarly, some firms are reluctant to enter an e-marketplace if certain other competitors do not participate (Kaplan and Sawhney, 2000). Indeed, motivations for joining exchanges differ markedly for buyers and suppliers 
(Barratt and Rosdahl, 2002). Some suppliers have appeared reluctant to trade via e-marketplaces, harbouring concerns with:

i. Transparency - where buyers can identify the prices suppliers are paying, allowing them to potentially force suppliers to acquiesce to lower prices;

ii. Standardisation - information provided in a form leading buyers to seek common terms such as payment options, dates or financial terms;

iii. Ease of comparison - being able to identify new suppliers and consequently to bypass existing channel members;

iv. Share capital ownership - where there is a bias towards powerful buyers;

v. Reverse auctions - where the buyer sets a price and suppliers bid for it with prices typically falling during the auction, and

vi. Forced participation - where buying firms with large purchasing volumes are likely to force suppliers to join the network.

Based on: FTC/DOJ (2000); Jap and Mohr (2002); Hannon (2003); Min and Galle (1999); Howard et al. (2005); and Koch (2002a, b).

Developing the discussion of legal concerns, when e-marketplaces were first introduced many commentators considered it only a matter of time before they would be penalised for competition law infringements (Abrams, 2000; Labaton, 2000). To date, while no e-marketplace has been subject to formal investigation by the US Federal Trade Commission or the Department of Justice, these bodies have raised concerns as to the potential negative consequences e-marketplaces present for competition. Although the FTC and DOJ have given some early marketplaces such as Covisint (a major collaboration between DaimlerChrysler, Ford, and General Motors and joined later by Renault-Nissan and Peugeot-Citroen) and MyAircraft (initially a collaboration between US firms United Technologies and Honeywell International) a cautious 'green light' to operate, there is still the need for managers to be cognisant of any potential threat to the successful operation of e-marketplaces in order to be effective competitors and collaborators in emarketplace transactions. 
To date, the competition policy issues pertinent to e-marketplaces have been considered to some degree chiefly by lawyers, or else from a legal perspective (Dajani, 2001; Bailey, 2001; Sterling, 2001; Horton and Schmitz, 2002; Laflamme and Biggio, 2001). In comparison, studies dedicated to an industrial marketing audience highlighting pertinent competition policy issues related to e-marketplaces are largely absent (Fontenot and Hyman, 2004; Lichtenthal and Eliaz, 2003). Although marketers are increasingly confronted by a number of legal and regulatory challenges (Petty, 2005) a general criticism of marketing practice and theory maintains that marketers have been perceived to be reluctant to engage in policy discussions (Czinkota, 2000). The scope of government policy and law which regulates marketing activity has expanded significantly in most developed nations (Le Clair 2000; Petty 1999, 2005). Indeed, a number of authors (Le Clair et al. 1997; Gundlach and Phillips, 2002; Fontenot and Hyman, 2004) have recently identified that US antitrust or competition law presents a significant challenge to forms of marketing.

Ascertaining the dimensions of these regulatory concerns therefore is important for marketing managers. Indeed, many marketing managers may not realise the growing likelihood of violating antitrust or competition laws (Bush and Gelb, 2005) with many business crimes caused by employees who often unknowingly break the law pursuing firms' objectives (Le Clair, 2000). The consequences of these violations can be severe for both the firm and individual employees. For example, under the US Sherman Act, corporations which violate antitrust law face a maximum fine of $\$ 10$ million. ${ }^{1}$ Employees, such as marketing managers, face a maximum penalty of three years imprisonment and a $\$ 350,000$ fine for practices that restrict trade or monopolise markets.

\footnotetext{
${ }^{1}$ In the USA, the maximum $\$ 10 \mathrm{~m}$ fine level may be increased under some circumstances. For example in 2004, German memory chip maker Infineon Technologies was fined $\$ 160$ million for breaching US antitrust law by engaging in price fixing in its dynamic random access memory (DRAM) chip market. A number of senior managers within this firm, including both US and non-US citizens, have both paid maximum fines and served time in US jails for these offences. The Sherman Antitrust Act carries a maximum penalty of three years imprisonment.
} 
Against this background, potentially anticompetitive features of B2B emarketplaces are identified. Conduct and behaviour of firms participating in emarketplaces are suggested in order to mitigate competition policy concerns.

\section{Competition Policy concerns and e-marketplaces: Generic challenges and implications for practitioners}

Despite the reported benefits of e-marketplaces, concerns have been raised that they enable collaboration and potentially restrict competition between buyers and suppliers. The competitive concerns of regulatory agencies toward e-marketplaces relate to two areas (FTC, 2000; FTC/DOJ, 2000). Initially, concerns arise with the characteristics of e-marketplaces including how information is shared between firms, misuses of buyer power (or monopsony) and the potential exclusion or over-inclusion of firms from exchanges. Additionally, the actual market for e-marketplaces may pose questions of competitiveness. This issue is exacerbated following the consolidation of some e-marketplaces such as 'CPGMarket', 'Pantellos' and 'TradeRanger' (McBride, 2005). The dimensions of these anticompetitive concerns are considered in turn and are illustrated by an examination of $116 \mathrm{e}-$ marketplaces across five broad industrial markets spanning electronics and electrical products to science and engineering goods and services (see Appendix).

\subsection{Markets for goods bought and sold on e-marketplaces}

\section{Information sharing}

The premise of the Internet is a means to exchange information more easily and at higher speeds. E-marketplaces subsequently have the capacity to facilitate increased data sharing over the Web and improve the quality of information available to both buyers and sellers. This offers clear benefits as e-marketplaces allow real-time access to information such as product availability, prices and other competitive terms. While greater information availability will be likely to encourage competition and benefit markets "...information-sharing agreements in the context of B2Bs [e-marketplaces] could facilitate coordination on price or other competitive terms and thereby be likely to injure competition" (FTC, 2000, part 3, p.3). This position is 
problematic as the distribution of information to firms which are traditionally competitors is an important precursor to full participation in an e-marketplace (Eng, 2004).

Greater transparency also allows companies to collude in price fixing or other conditions of sale. These forms of information sharing have long been central concerns of US antitrust law. Agreements to share information form part of section 1 of the Sherman Act under the 'rule of reason' which prohibits activities by buyers or suppliers that restrain trade (although some forms of agreements such as blatant price fixing are per se illegal). Further, section 2 of the Sherman Act indicates when information sharing leads to activities by buyers or suppliers to monopolise (or attempt to monopolise) a market. The difficulty in interpreting this law lies in identifying when information-sharing agreements are competitive and when competition is damaged. In general, companies should consider: who has access to competitively sensitive information and to what types of information; how current and transactionspecific the information is; if the information is already available through alternative sources; and the structure of the market served by the collaborating companies (Laflamme and Biggio, 2001).

A critical element when assessing how information is assembled and used within e-marketplaces is the ownership and/or control of these entities. Competitive concerns are likely to arise when e-marketplace owners who participate in the market fail to share sensitive information appropriately. Emarketplaces owned by a small number of powerful firms could use this transactional information (e.g. price and quantity data) to adjust their own marketing/pricing strategies gaining a competitive advantage. Strategic and price transparencies may then occur as participants in an e-marketplace can see how and why other firms are pricing their products. For example, Covisint caused concern among automotive suppliers and the FTC, as initially the major equity holders were a combination of major automotive manufacturers. Subsequently, concerns were raised that these buyers might use this access to information opportunistically (Koch, 2002a, b). Lastly, many e-marketplaces will generate and often sell aggregated information of transactions data for 
marketing purposes. This often important income generation opportunity for emarketplaces also poses substantial competition policy concerns.

\section{Reducing the negative impact of information sharing}

All e-marketplaces act as intermediary bodies and should be responsible for collating and disseminating information to market participants. The process of the distribution or sharing of information and its security concerns managers most when participating in e-marketplaces (Zhu, 2004; Kehng and AlHawamdeh, 2002; Forrester Research, 2000). Firms are wary of creating 'over' transparency via e-marketplaces as there are risks in exchanging strategic information with other companies. However, when using emarketplaces companies often need to provide sensitive information such as prices, volume and procurement needs which could be used unscrupulously. Although the FTC/DOJ (2000) guidelines require 'safeguards' to be put in place to limit some parties' access to sensitive information, they fall short of suggesting what would be appropriate to industrial marketers.

Given that site security is a major concern of e-marketplace participants, it was unsurprising that our examination of B2B e-marketplaces (see Appendix) indicated that the majority of sites $(55 \%)$ emphasised information security protocols, often citing specific security devices utilised to protect data captured (e.g. firewalls, secure socket layer, encryption devices), including certification for secure information handling in the case of one site (SupplyOn). In terms of how data were used and disseminated by marketplaces, $23 \%$ of exchanges claimed not to share information with any other party, instead using it only for site purposes; $13 \%$ only shared information to third parties if consent was given; whilst $46 \%$ used information captured on transactions for marketing purposes (typically targeting offers to site participants). In the case of $18 \%$ of sites, no criteria were disclosed (or else were unavailable) concerning how information was used.

A small minority of exchanges had some form of competition law or ethical guidelines available for participants to consult (5\%); $3 \%$ of sites employed safeguards controlling the information accessible to employees and board 
members; and $6 \%$ of exchanges had a privacy or compliance officer. Finally, of the sites examined, less than half (43.9\%) emphasised their independence/neutrality or else made no mention of a particular bias. Only in the case of a small minority of sites (3\%) was a bias declared and then this was directed towards the supply side, with no obvious buy side bias among the sites sampled. Based on the sites examined:

i. A sizeable proportion of exchanges (45\%) made little or no mention of site security;

ii. The bulk of exchanges intended to use participants' transaction information for marketing purposes including third party usage;

iii. Few sites provided ethical guidelines or referred specifically to antitrust or competition law; and

iv. Despite the majority of sites sampled being open to all credible buyers and suppliers within a particular industry (and comprising third-party owned exchanges), less than half emphasised their neutrality.

To reduce the possibility of the unscrupulous use of information, emarketplaces and participating firms need to control the flow of information both horizontally (between competitors) and vertically (both upstream and downstream in the supply chain) (Dajani, 2001), and need this to be emphasised to participants. This control is particularly important when one party does not know the identity of the prospective buyer or supplier. A number of approaches are used to achieve this regulation of information use, including the ownership of e-marketplaces, curbs on personnel using sensitive information, the use of legal resources and internet security. Joining a neutral market or exchange which is not owned by either buyers or suppliers is an initial step in reducing these informational concerns. For example, VertMarkets specialises in e-marketplaces operating some 68 sites spanning electronics markets to the public sector. As VertMarkets are not owned by either buyers or suppliers in their focal markets they are seen as being independent particularly if they carefully manage the data captured from their sites. Within a neutral market data on transactions and other business captured from the site are controlled by an independent third party. 
Subsequently, access to competitively sensitive information can be limited to specific personnel which can be bound by confidentiality/non-disclosure agreements outlining who will have access to data. Confidentiality agreements should also include persons working for an exchange on temporary assignment from a participating firm. Since its inception, FreeMarkets, an electronic marketplace for a diverse range of hi-tech and pharmaceutical goods, has used non-disclosure agreements. Similarly MetalSite, a marketplace for steel, provided its employees with antitrust or competition law training and required them to sign confidentiality agreements (FTC, 2000). Further, engaging an antitrust or competition lawyer at board meetings and to periodically audit e-marketplace participant behaviour would also help ensure that these conditions are upheld.

Ensuring the physical security of the information systems adopted is a logical step in limiting unauthorised access to e-marketplace data. It is often pertinent for the software underpinning an exchange to be designed by an independent agency. Such an impartial body can monitor who has access to the software, including access codes and user recognition software that could potentially identify participants. Further, the use of firewalls and other methods of physically limiting unauthorised access to sensitive information are also important, with some marketplaces being early adopters of this technology. For example, SupplyOn was one of the first marketplaces to gain independent certification for their information security management system (BS 7799-2 and ISO 27001) as well as committing to independent monthly and annual security and risk audits. Clear operating guidelines should also help reduce suppliers' fears in participating. VW's private GroupSupply exchange emphasises to suppliers that sensitive data are only exchanged between the supplier and VW, thus greatly reducing transparency and potential standardisation issues. Similarly, SupplyOn state their exchange should:

i. Handle customer data with high confidentiality and integrity;

ii. Meet the highest security standards in all company departments;

iii. Secure long term business operations of SupplyOn; and

iv. Minimise the risks of human failure or abuse.

Source: SupplyOn.com. 
Managers also need to be aware that many e-marketplaces' aggregate data that will be distributed to members or sold to third parties in order to increase site income. This is particularly the case for third-party owned industrial marketplaces. For example PartMiner, a major exchange for electronic components, like most of its contemporaries reserves the right to use aggregate data for sales or marketing purposes. How these aggregated data are treated and disseminated is a potential competition policy concern. Although no specific business-to-business guidelines exist, the joint FTC/DOJ antitrust principles for disseminating competitor data provides useful guidance for the management of e-marketplace aggregated data, stipulating that:

i. A third party manages the survey;

ii. The information collected is more than three months old;

iii. A minimum of five companies reported the data;

iv. No individual company accounts for more than $25 \%$ of the data; and

v. The information reported is anonymous.

Source: Health Care and Antitrust Statements (DOJ/FTC, 1996).

Figure 2: Information sharing: A guide for self-regulation ${ }^{2}$

\begin{tabular}{|c|c|c|}
\hline $\begin{array}{c}\text { Problematic } \\
\text { behaviour }\end{array}$ & $\begin{array}{c}\text { Competition } \\
\text { warning signs }\end{array}$ & Remedies \\
\hline $\begin{array}{l}\text { Information- } \\
\text { sharing } \\
\text { agreements } \\
\text { and } \\
\text { procedures. }\end{array}$ & $\begin{array}{l}\text { The exchange } \\
\text { is owned and } \\
\text { controlled by } \\
\text { dominant firms } \\
\text { on either the } \\
\text { supply or } \\
\text { buying side of a } \\
\text { market. }\end{array}$ & $\begin{array}{c}\text { Allow sellers/buyers access to other parties' prices } \\
\text { (if appropriate) but not their identity such as in the } \\
\text { case of competing firms. } \\
\text { Use legal barriers including non- } \\
\text { disclosure/confidentiality agreements, antitrust and } \\
\text { competition law training for personnel, and } \\
\text { technical barriers (e.g. firewalls) to safeguard } \\
\text { information. }\end{array}$ \\
\hline $\begin{array}{l}\text { Access to } \\
\text { competitively } \\
\text { sensitive } \\
\text { information. }\end{array}$ & $\begin{array}{l}\text { Exchange } \\
\text { directors are } \\
\text { employees of } \\
\text { dominant } \\
\text { participant } \\
\text { firms. }\end{array}$ & $\begin{array}{l}\text { Obtain certification to demonstrate information } \\
\text { security to participants (e.g. BS 7799-2). } \\
\text { Limit - or disallow - access to sensitive } \\
\text { information to board members particularly those } \\
\text { employed by participating firms. }\end{array}$ \\
\hline
\end{tabular}
${ }^{2}$ Self-regulation of legal guidelines should not necessarily be interpreted as 'do-it-yourself' regulation (Fontenot and
Hyman, 2004), but rather, performed by an independent and neutral organisation (Hicks, 2000). 


\begin{tabular}{|c|c|c|}
\hline $\begin{array}{l}\text { The } \\
\text { collection, } \\
\text { treatment } \\
\text { and } \\
\text { disseminatio } \\
\mathrm{n} \text { of } \\
\text { aggregated } \\
\text { data. }\end{array}$ & $\begin{array}{l}\text { Personnel } \\
\text { working for the } \\
\text { exchange are } \\
\text { on temporary } \\
\text { assignment } \\
\text { from a } \\
\text { participating } \\
\text { dominant firm. }\end{array}$ & $\begin{array}{l}\text { Appoint neutral board members (i.e. not employed } \\
\text { by any equity owners of the exchange). } \\
\text { Commit to regular antitrust and competition law } \\
\text { audits to assess the degree to which participants } \\
\text { are adhering to the rules of the exchange. } \\
\text { Penalise those who violate operating rules. } \\
\text { Follow DOJ/FTC (1996) guidelines for the } \\
\text { collection and treatment of aggregate data. }\end{array}$ \\
\hline
\end{tabular}

Beyond these concerns managers responsible for data dissemination need to ensure that only historical data are made equally available to buyers and suppliers. Further, information should not be analysed or commented upon, thus leaving participants to decide independently what use to put it to. In addition to the guidance offered above, encouraging employees to follow codes of conduct by bodies such as the Institute for Supply Management (ISM) should help highlight antitrust or competition policy issues. The ISM calls on members to 'Handle confidential or proprietary information with due care and proper consideration of ethical and legal ramifications and governmental regulations' and, more generally, 'Know and obey the letter and spirit of laws applicable to supply management' in their 'Principles and Standards of Ethical Supply Management Conduct' (ISM, 2005). Figure 2 highlights the major of areas of concern and outlines remedies for information sharing.

\section{Monopsony - misuses of buyer power}

Competition law originally developed to curb the influence of powerful sellers who restricted competition and had the ability to increase prices to consumers (Kirkwood, 2004). Similar concerns latterly arose based on the emergence of large, powerful buyers that had the potential to restrict competition, through 'monopsonistic behaviour'. These 'oligopsony' concerns occur when powerful buyers with a significant share of the buying market collude to influence prices or other terms of exchange. For example, larger buyers participating in an emarketplace might derive better prices through volume discounts. Also when buyers are relatively few in number and interact frequently the potential for collusion exists (Tyagi, 2001). If buyers are able to share information about transactions through e-marketplaces this could lead to tacit collusion on prices 
paid and charged in output markets. Similarly, if information is shared among buyers relating to "payment options, payment dates, financing terms and perhaps even warranties" this might lead to buyers forcing the 'standardisation' of these terms (FTC, 2000, part 3, p.4). For example, sections 1 and 2 of the Sherman Act prohibit activities that restrain trade or attempt to monopolise a market which applies equally to buyers as well as suppliers. Plaintiffs have to demonstrate (under a 'rule of reason' analysis) that a defendant's behaviour was likely to reduce rather than increase consumer welfare (Kirkwood, 2004).

Not all e-marketplaces allow joint purchasing. Where joint purchasing is prohibited buyers might circumvent such site rules and co-ordinate their buying with other firms via an agent (FTC, 2000). Although buyers participating in an e-marketplace might derive better prices through volume discounts, instances where participants have agreed to purchase exclusively through the exchange could also increase instances of opportunistic monopsony power being exercised. Buyer power could also be exercised through reverse auctions. In the case of Covisint (created by large automotive firms) many suppliers considered reverse online auctions - a key feature of the exchange - as a market test for the buyer. Suppliers felt that these motives accounted for as much as $80 \%$ of reverse auctions held on the site (Hannon, 2003) leading to its initial rejection by some suppliers (Hannon, 2004) who were concerned that they would be forced to acquiesce to the demands of powerful buyers. In comparison, SupplyOn was created by major German automotive suppliers (including Robert Bosch and Continental) in an attempt to deflect the power of large buyers.

\section{Reducing the negative impact of monopsony}

The major monopsony concerns of policy makers and managers include joint purchasing arrangements, the 'standardisation' of terms of trade, and reverse auctions. Our examination of active e-marketplaces revealed no information pertaining to joint purchasing rules or volume agreements for any of the sites sampled. In terms of online auctions, although $25 \%$ of sites held auctions, only $9 \%$ featured reverse auctions. Only in the case of three exchanges $(2.5 \%$ 
of sites) did they specifically note the use of identity tracking software. Although some sites will inevitably be owned by the buying side, many exchanges emphasised their independence/neutrality or else made no mention of a particular bias as noted earlier.

In terms of practical remedies, for joint purchasing, it is advisable for emarkets to attempt to prohibit the practice. Such steps will hopefully make the facilitation of price fixing more complex and reduce the apprehension of suppliers. This line was taken by the founders of Covisint who stipulated in their initial operating guidelines that:

i. [Covisint] Will not aggregate the purchases of one firm with those of another;

ii. Will not offer aggregated purchasing services for any automotivespecific parts or materials; and

iii. Aggregated purchases of non-automotive specific parts (such as office supplies, cleaning suppliers etc.) will always be within the applicable competitive law guidelines in which the purchases are made.

Source: Covisint website (Dajani, 2001).

Although buyers may use joint purchasing to lower prices, potentially raising antitrust and competition concerns (Barratt and Rosdahl, 2002), it is not per se illegal with two 'safe harbours' existing for companies participating in emarketplaces. Under this ruling, competitors can collectively:

i. Purchase up to $35 \%$ of the total sales of the goods and services in a market (in order to reduce the risk of buyer market power); and

ii. Purchase goods that represent no greater than $20 \%$ of the participant's output revenues (in order to avoid price fixing in downstream markets)

Source: (DOJ/FTC, 1996).

Other practical measures could include: limiting purchases made by participants under joint agreements or by using quotas, monitoring the market share of the buying group, and restricting the number of participants involved 
in joint purchases. In the case of reverse auctions - where buyers might be able to manipulate proceedings - e-marketplaces may use controls. These controls include identity software to ensure that false bidding by buyers does not take place (a practice referred to by practitioners as 'shilling') and that the result of the auction is honoured in order to avoid 'market tests' by some unscrupulous buyers. Although some exchanges may be tempted to prohibit reverse auctions outright, they might be inadvertently limiting suppliers' greater exposure to potential buyers.

Figure 3: $\quad$ Monopsony: A guide for self-regulation

\begin{tabular}{|c|c|c|}
\hline $\begin{array}{l}\text { Problematic } \\
\text { behaviour }\end{array}$ & Competition warning signs & Remedies \\
\hline $\begin{array}{l}\text { The extent to } \\
\text { which a buyer } \\
\text { or a group of } \\
\text { buyers can } \\
\text { feasibly } \\
\text { coordinate } \\
\text { activities to } \\
\text { dominate a } \\
\text { market with the } \\
\text { intent to lower } \\
\text { prices (via joint } \\
\text { purchasing, } \\
\text { reverse } \\
\text { auctions etc.). }\end{array}$ & $\begin{array}{l}\text { A high proportion of joint } \\
\text { purchasing initiatives } \\
\text { particularly by dominant } \\
\text { buyers. } \\
\text { Unexplainably low prices in } \\
\text { comparison to rival } \\
\text { exchanges and off-line } \\
\text { markets. } \\
\text { Suppliers complain to } \\
\text { antitrust or competition law } \\
\text { agencies about the extent of } \\
\text { buyer coercion. } \\
\text { The site is predominantly } \\
\text { owned by dominant buyers. }\end{array}$ & $\begin{array}{l}\text { Prohibit joint purchasing. } \\
\text { If joint purchasing is to be permitted } \\
\text { then follow FTC/DOJ 'safe harbour' } \\
\text { guidelines. Through prohibiting } \\
\text { additional firms participating in joint } \\
\text { purchases beyond specified } \\
\text { thresholds, and/or by using a quota } \\
\text { system. } \\
\text { Employ identity software to track } \\
\text { participants involved in reverse } \\
\text { auctions and to ensure that false } \\
\text { bidding by dominant buyers does } \\
\text { not take place. }\end{array}$ \\
\hline
\end{tabular}

The concerns related to 'standardisation' are likely to be unfounded for the majority of firms participating in e-marketplaces. Most industrial markets deal in non-standardised products and components (such as is the case in the automotive, semiconductor and aerospace markets) making the standardisation of the terms of trade highly problematic based on firms with unique offerings. Further, most companies prefer establishing relationships with suppliers and operate under a 'total cost' situation, where price is one of a number of important criteria along with other factors such as augmented services or order cycle time (Lichtenthal and Eliaz, 2003), therefore making standardisation unlikely. When concerns persist, however, the standardisation of terms can be reduced by adopting some of the previously discussed 
guidance for information sharing in order to reduce the dissemination of commercially sensitive information. Figure 3 highlights the major areas of monopsony concern and potential remedies.

\section{Exclusion/over inclusion of new participants}

While most e-marketplaces are open to all who qualify as buyers or suppliers, in some cases membership can be prohibited for other than appropriate reasons (such as poor credit history or abuse of the sites' terms and conditions). Similarly, firms may be coerced into using certain e-marketplaces rather than an exchange of their choosing. Antitrust and competition legislation such as the Sherman Act views such exclusion from, or over inclusion in, a market as a concern when this damages competition rather than individual competitors (FTC, 2000). Damage to competition must clearly be demonstrable including the extent of the disadvantage that firms experience by being excluded or having limited access to a marketplace. Competiton concerns also arise with the 'over inclusion' of firms in an emarketplace by persuading or compelling firms to use an exchange to the exclusion of other marketplaces (FTC, 2000).

These issues of competitor exclusion can occur when a select group of firms (including e-marketplace owner-participants) wishes to create more integrated and synchronised operations (Axelsson and Wynstra, 2002). Such a consortium of owner-participants might involve a small circle of powerful buyers and/or sellers, each with an equal interest in preserving the status quo which affords participants favourable treatment through entry barriers or reduced costs (Fontenot and Hyman, 2004). For example, if an e-marketplace leads to the realisation of considerable efficiencies, the participant-owners could refuse or limit access to their competitors (FTC, 2000).

In some instances the operating rules of the e-marketplace may limit participants' access to other competing exchanges. For example, emarketplace owner-participants might be forbidden from using or investing in rival exchanges or be required to conduct a specified quantity of their business through the exchange (Laflamme and Biggio, 2001). If this leads to 
powerful buyers concentrating most of their purchasing through a particular exchange it may harm competition, leaving little business for competing exchanges. In this situation, a rival exchange may find it impossible to compete with the incumbent e-marketplace for the sector (Laflamme and Biggio, 2001). The damaging effects of exclusion are likely to be greatest where an e-marketplace is important for developing competition in an industry, leading to a situation where competition can be adversely affected by exclusion. The damage to excluded parties might include rebates of fees unavailable to participants' rivals, information presented in a manner that benefits the owners of the e-marketplace, and disadvantageous access to owners' rivals that could ultimately raise the costs incurred by competitors excluded from the marketplace (FTC, 2000). Discrimination by e-marketplace owners/founders may restrict market entry to existing and new competitors reducing opportunities particularly for smaller suppliers.

Reducing the negative impact of exclusion/over inclusion of new participants As noted, the major issues concerning exclusion/over inclusion for emarketplaces relate to the prohibition of membership and use of rival exchanges. Based on the e-marketplaces examined, the results indicate that numerous independent exchanges operate in markets where negligible switching costs apply. 90 of the e-marketplaces examined ( $78 \%$ of sites) allowed buyers and suppliers to join by completion of an (often brief) online registration form; 24 exchanges $(21 \%)$ stipulated some form of qualification (e.g. creditworthiness, quality/reliability), or required either the buyer or supplier to be based in a particular country; while two exchanges did not disclose any membership criteria. In terms of costs, 53 marketplaces $(46 \%$ of sites) charged variable fees based on services used, 16 sites (14\%) charged a time-based fee (either annually, quarterly or monthly), 12 sites (10\%) were free, with the remainder levying a charge to either the supplier (22 sites, 19\%) or buyer (nine sites, $8 \%$ ). Five sites offered trial periods (in some cases this incurred a minimal charge) while four sites did not disclose their fees. Based on the e-marketplaces examined, the evidence indicated that: 
i. Firms would not be excluded from membership of an exchange for reasons other than poor credit history or as a nonqualified buyer/seller;

ii. No exclusivity or volume agreements could be identified for any exchange; and

iii. No switching costs were identified other than the loss of any upfront fees paid if trading through an exchange ceases.

The FTC and DOJ offer little by way of guidance as to what constitutes being too exclusive or inclusive, although market share of participating firms is widely used to provide an indicator of dominance within a sector (Werden, 2002). Membership and potential exclusion was the motivation behind the FTC's initial concerns of Covisint triggered by its powerful founding members. Covisint, however, adopted an inclusive attitude encouraging membership among other automotive firms and suppliers, although some manufacturers decided to create their own e-marketplace as was the case with the Volkswagen Group and 'GroupSupply'.

Despite these concerns, the exclusion of firms from an e-marketplace on the grounds of being a competitor seems unlikely as many exchanges are independent and operate with a profit motive. To date, no marketplace has developed an unassailable position with in excess of 1000 independent exchanges in existence serving most industries (eMarket Services, 2007). Under such conditions exclusion of potential users would ultimately be selfdefeating. Reducing the number of suppliers participating allows buyers temporarily to negotiate lower prices, yet limits buyer choice over time. Conversely, restricting potential buyers might cause suppliers to defect to rival exchanges. Indeed, many exchanges have thrived on developing a wide and diverse range of users. For example, although SupplyOn was initiated by major automotive suppliers concerned about the extent of buyer power, its success is dependent on attracting major buyers. The site now has some 25,000 users from over 8,500 companies operating in 30 different countries including major manufacturers such as BMW. In summary, if an exchange is 
to be successful it requires open access. These concerns and remedies are summarised in Figure 4.

Figure 4: Exclusion/over inclusion of new participants:

\begin{tabular}{ccc}
\hline $\begin{array}{c}\text { Problematic } \\
\text { behaviour }\end{array}$ & Competition warning signs & Remedies \\
\hline $\begin{array}{c}\text { Firms are } \\
\text { excluded from } \\
\text { an e- } \\
\text { marketplace. }\end{array}$ & $\begin{array}{c}\text { Large market share of participants. } \\
\text { excluded from e-marketplaces for } \\
\text { reasons other than poor credit history } \\
\text { or relevant qualifications. }\end{array}$ & $\begin{array}{c}\text { Allow participants to invest } \\
\text { in, or trade via, other } \\
\text { marketplaces thus } \\
\text { demonstrating a pro- } \\
\text { competitive and inclusive } \\
\text { attitude. }\end{array}$ \\
\hline $\begin{array}{c}\text { Firms are } \\
\text { compelled or } \\
\text { coerced into } \\
\text { using one }\end{array}$ & $\begin{array}{c}\text { Volume agreements lead to } \\
\text { concentrated purchasing by dominant } \\
\text { firms. }\end{array}$ & $\begin{array}{c}\text { Eliminate volume } \\
\text { agreements. } \\
\text { volume by }\end{array}$ \\
$\begin{array}{c}\text { agreements, or } \\
\text { other means. }\end{array}$ & $\begin{array}{c}\text { Firms complain to antitrust or } \\
\text { competition agencies that they are } \\
\text { being disadvantaged by being } \\
\text { excluded, or else, having limited } \\
\text { access to a marketplace. }\end{array}$ & $\begin{array}{c}\text { Ensure ease of membership } \\
\text { unless justified (e.g. }\end{array}$ \\
$\begin{array}{c}\text { qualified sellers', specialist } \\
\text { defence systems, or } \\
\text { excluding 'free riding' by } \\
\text { non-owner members). }\end{array}$ \\
\hline
\end{tabular}

\subsection{The market for e-marketplaces}

The final e-marketplace antitrust or competition policy concern is the market for, and the level of competition between, e-marketplaces (FTC, 2000). The FTC has expressed concerns that the development of B2B e-marketplaces and services might undermine the level of competition for e-marketplace creation. The level of competition for e-marketplaces will be affected by the scale of 'network effects' which exist when "...the value of a product to one user depends on how many other users there are" (Shapiro and Varian, 1999, p.13). For example, new exchanges created within an industry by existing players will have a first-mover advantage and potentially considerable network effects as firms are often attracted to larger networks.

An exchange that creates a lead in a sector - through technical or marketing reasons - may draw in enough firms establishing itself as the 'market maker' for the sector. Such a marketplace could exert a powerful effect on competition between e-marketplaces with buyers or sellers encouraged to deal with this particular exchange excluding others. This could be facilitated 
through incentives such as rebates or revenue sharing, or rules such as minimum volume requirements or prohibitions on investment in other emarketplaces (FTC, 2000). These conditions amount to switching costs providing both benefits of membership and potential penalties that can lock participants de facto into the exchange. Similarly, when a group of firms in a network invest resources to integrate new technology and operations, participants become dependent and find exit problematic (Axelsson and Wynstra, 2002). This behaviour undermines market competition and the development of alternative marketplaces, leading to higher prices, less efficient service, and reduced innovation due to complacency (FTC, 2000). Under section 3 of the Clayton Act, agreements between firms to not use or deal in the goods of competitors are prohibited. Similarly, under the Sherman Act, regulatory agencies might view such behaviour as tantamount to a 'group boycott', or to refusal to deal with firms excluded from a dominant emarketplace.

Reducing the negative impact in the market for e-marketplaces

The expectation that exchanges would have negative network effects has not manifested as anticipated with more than 1000 independent exchanges in operation (see Table 1). Subsequently, concerns as to the exclusivity of exchanges appear unfounded.

Table 1: $\quad$ Number of Independent B2B E-marketplaces by Industry

\begin{tabular}{llll}
\hline \multicolumn{1}{c}{ Industry } & $\begin{array}{c}\text { No. of } \\
\text { sites }\end{array}$ & \multicolumn{1}{c}{ Industry } & $\begin{array}{c}\text { No. of } \\
\text { sites }\end{array}$ \\
\hline Advertising \& Media & 6 & Industrial Machinery & \& \\
Agriculture & 34 & Equipment & 42 \\
Arts \& Entertainment & 3 & IT Products \& Services & 9 \\
Automotive & 18 & Maritime Products \& Services & 22 \\
Aviation & 14 & Metal \& Mining & 36 \\
Biotechnology & 8 & Maintenance \& Repair & 216 \\
Building \& Construction & 33 & Multiple Industry & E- \\
Chemicals & 20 & marketplaces & 8 \\
Defence & 8 & Office Equipment & 8 \\
Education \& Training & 8 & Other Industries & 6 \\
Electronics \& Electrical & 38 & Packaging & 15 \\
products & 28 & Paper \& Pulp & 31 \\
Energy \& Fuels & 14 & Plastics \& Rubber & 7 \\
Environment & 16 & Pre-owned/Second-hand & 7 \\
Excess Inventory and Barter & 23 & Goods & 20 \\
\hline
\end{tabular}




\begin{tabular}{llll}
\hline Finance \& Insurance & 47 & Printing & 7 \\
Food \& Beverage & 18 & Real Estate & 18 \\
Forestry \& Wood & 59 & Retail \& Consumer Goods & 13 \\
Government \& Public Sector & 29 & Science \& Engineering & 26 \\
Healthcare \& Pharmaceutical & 14 & Services & 36 \\
Hospitality \& Leisure & & Telecommunication & Bandwidth \\
& & Textiles \& Leather & \\
& & Transportation \& Logistics \\
\hline
\end{tabular}

Source: eMarket Services (2007)

In terms of the sites examined, no e-marketplace could be identified that stipulated participants could not engage in trade with other sites (with suppliers allowed to post multiple offers on competing sites), although the extent of interoperability between sites was unclear. If an exchange intends not to admit all competitors for some reason then it might be seen to violate antitrust or competition law (Dajani, 2001). The evidence highlighted above suggests that this is not likely to be the case. Even for private exchanges such as VWGroupSupply, although Volkswagen handles $90 \%$ of their global purchasing volume via the exchange, their market share in 2006 - at less than $4 \%$ of the US market and $11 \%$ of the European market - is unlikely to trouble US or European competition authorities. Figure 5 summarises the major areas of concern and suggests remedies.

Figure 5: The market for e-marketplaces: A guide for self-regulation

\begin{tabular}{|c|c|c|}
\hline $\begin{array}{c}\text { Problematic } \\
\text { behaviour }\end{array}$ & Competition warning signs & Remedies \\
\hline $\begin{array}{l}\text { Limited } \\
\text { competition } \\
\text { between } \\
\text { marketplaces in an } \\
\text { industry (e.g. low } \\
\text { switching rates). }\end{array}$ & $\begin{array}{l}\text { Concentrated marketplaces in } \\
\text { focal industries with dominant } \\
\text { market players. } \\
\text { Incentives/minimum volume } \\
\text { requirements. }\end{array}$ & $\begin{array}{c}\text { Allow suppliers to post } \\
\text { multiple offers on competing } \\
\text { sites and do not prohibit } \\
\text { parties from using rival } \\
\text { exchanges. } \\
\text { Minimise volume } \\
\text { agreements. }\end{array}$ \\
\hline $\begin{array}{l}\text { Barriers exist } \\
\text { (natural or } \\
\text { artificial) to } \\
\text { preclude firms' } \\
\text { participating in } \\
\text { rival exchanges. }\end{array}$ & $\begin{array}{l}\text { Participants prohibited from } \\
\text { using rival exchanges (firms are } \\
\text { excluded from freely selecting a } \\
\text { trading partner). }\end{array}$ & $\begin{array}{l}\text { Minimise switching costs } \\
\text { and entry barriers. }\end{array}$ \\
\hline
\end{tabular}

\section{E-marketplaces and competition policy - tentative conclusions}


Historically, the assessment of latest developments in government policy and law for marketing practice was a prominent topic within the marketing literature (e.g. Engle, 1936, Nystrom 1936, McNair 1938, Edwards 1950). Despite the importance previously placed on legal and regulatory concerns, the legality of marketing actions has attracted less attention in recent years (Czinkota, 2000). This decline, associated with the changing perception of marketing to being solely an organisational function (Petty, 2005), has not been associated with any decline in the importance of government policy and legislation. Conversely, the scope of government policy and law which regulates marketing activity has expanded significantly in most developed nations (Gundlach and Phillips, 2002; Le Clair 2000; Petty 1999, 2005). In the current context, e-marketplaces provide a platform that facilitates more efficient supply chain management and a means to forge relationships with a larger number of parties. As such, e-marketplaces are changing the mechanics of competition in most industries for the better by providing opportunities for increasing supply chain management efficiencies. However, whilst firms are being encouraged to build relationships that are hard for competitors to imitate or displace (Day, 2000) and to move towards 'coopetition' - the simultaneous cooperation and competition between organisations (Sharma, 2002) - antitrust or competition issues may arise (Fontenot and Hyman, 2004). Even if antitrust or competition policy issues do not persist, understanding the 'rules' of competition will offer firms an insight into what constitutes a 'competitive' online exchange. Consequently, understanding the antitrust and competition policy implications of emarketplaces is important for marketers to comprehend, particularly as they are now a common feature of the commercial landscape.

E-marketplaces are currently at an interesting - and early - point in their development. The last few years have witnessed e-marketplace closure as well as the consolidation of a number of exchanges. Those remaining (including new entrants) are under considerable pressure to deliver on the supply chain benefits often optimistically promised. More crucially, supply chain efficiencies aside, e-marketplaces will have to clearly demonstrate that 
their operating rules and procedures do not harm competition or individual firms.

The anticompetitive issues that relate to e-marketplaces are not unique in the sense that they are covered by existing legislation. They do, however, allow larger numbers of players to interact more effectively and potentially to collaborate than many existing technologies such as the telephone network. Although a grey area currently exists concerning B2B e-marketplaces and legislation, with US Government Agencies such as the FTC and DOJ adopting a fairly liberal and supportive attitude, competition agencies will be quick to act if there is the possibility of competition law violations. As most developed countries have antitrust/competition legislation informed by the US model (Djelic, 2002), the implications and issues discussed in this study including proposed conduct are generalised to other country contexts.

Online marketplaces are likely to benefit most markets by being procompetitive rather than reducing market competition. Their potential, however, to negatively impact on competition (and individual firms) is considerable. In particular, firms need to pay attention to governance structures, operating rules and procedures when creating and participating in e-marketplaces, and potential competition issues when new technologies afford competitors greater opportunities to collaborate.

Although most e-marketplaces will pose no anticompetitive concerns, their creation, maintenance and participation require firms' comprehension of competition guidelines. Consequently, practitioners would benefit from a range of future research. Initially, examining the creation of new emarketplaces can provide insights into the compliance procedures adopted prior to launch and in the marketing strategies adopted by new sites. Secondly, research examining established online exchanges would provide a better understanding of audit procedures and to identify who within the organisation is responsible for legal compliance (including antitrust and competition law). An important area for consideration beyond antitrust/competition legislation concerns the performance drivers of e- 
marketplaces. This is long overdue particularly as many online exchanges have existed since the 1990s. For example, are focused exchanges (i.e. those serving a narrowly defined market) more successful than sites serving fragmented markets? Are neutral exchanges more effective than private or consortia sites? In short, we need to understand the hallmarks of successful e-marketplaces from both the perspective of buyers, suppliers and site owners. 
Appendix: E-marketplaces and antitrust: information by selected industries*

\begin{tabular}{|c|c|c|c|c|c|c|}
\hline$x^{2}$ & $\begin{array}{l}\text { Electronics \& } \\
\text { Electrical } \\
\text { products }\end{array}$ & Automotive & Aviation & $\begin{array}{c}\text { Industrial } \\
\text { machinery \& } \\
\text { equipment }\end{array}$ & $\begin{array}{c}\text { Science \& } \\
\text { engineering }\end{array}$ & $\begin{array}{l}\text { Total } \\
(\%) \\
\end{array}$ \\
\hline $\begin{array}{l}\text { Estimated number of e- } \\
\text { marketplaces }\end{array}$ & 38 & 18 & 14 & 39 & 7 & 116 \\
\hline Information sharing & & & & & & \\
\hline $\begin{array}{l}\text { Information supplied to third } \\
\text { parties with consent }\end{array}$ & 11 & - & - & 2 & 2 & $15(13)$ \\
\hline $\begin{array}{l}\text { Information used for marketing } \\
\text { purposes }\end{array}$ & 18 & 14 & 5 & 11 & 5 & $53(46)$ \\
\hline $\begin{array}{l}\text { Do not pass information to other } \\
\text { parties (site use only) }\end{array}$ & 7 & 5 & 5 & 7 & 3 & $27(23)$ \\
\hline Information unavailable & 1 & 6 & 2 & 13 & - & $22(18)$ \\
\hline $\begin{array}{l}\text { Security devices used (e.g. } \\
\text { firewalls) }\end{array}$ & 25 & 10 & 8 & 16 & 5 & $64(55)$ \\
\hline $\begin{array}{c}\text { Explicit privacy/compliance } \\
\text { officer }\end{array}$ & 2 & - & 4 & 1 & - & $7(6)$ \\
\hline $\begin{array}{l}\text { Antitrust code of conduct/ethical } \\
\text { guide/governance/antitrust } \\
\text { training }\end{array}$ & 2 & 1 & - & 3 & - & $6(5)$ \\
\hline $\begin{array}{l}\text { Limits information accessible to } \\
\text { employees/board }\end{array}$ & 2 & - & 1 & 1 & - & $4(3)$ \\
\hline $\begin{array}{c}\text { Emphasises } \\
\text { independence/neutrality (bias, } \\
\text { e.g. supplier/distributor driven) }\end{array}$ & $32(2)$ & $5(1)$ & 2 & 10 & 2 & $51(43.9)$ \\
\hline
\end{tabular}


Appendix: E-marketplaces and antitrust: information by selected industries (Continued)

Monopsony

Reverse auction

Online auction

Joint purchasing rules

Identity software explicitly used

2
5
-

2

3

3

4
14
-

$\begin{array}{cc}- & 29(25) \\ - & - \\ - & 3(2.5)\end{array}$

Exclusion/over inclusion and market for marketplaces

Membership criteria

3

$-$

-

- Registration only

- Based on country

- Qualification

Excludes usage of other exchanges

- Not disclosed

29

3

6

Fees

- Variable

- Supplier fee

- Buyer fee

$$
\text { - Free }
$$

- Time based

- Not disclosed

- Trial period

-

10

$\begin{array}{ccc}16 & 11 & 28 \\ 1 & - & 2 \\ 1 & 3 & 8\end{array}$

$\begin{array}{ccc}28 & 6 & 90(78) \\ 2 & - & 6(5) \\ 8 & - & 18(16)\end{array}$

$-$

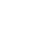

$$
-
$$

1

13
9
4
6
4
1
2

\begin{tabular}{ccccc}
7 & 7 & 19 & 7 & $53(46)$ \\
4 & 1 & 8 & - & $22(19)$ \\
1 & 1 & 3 & - & $9(8)$ \\
3 & 1 & 2 & - & $12(10)$ \\
2 & 3 & 7 & - & $16(14)$ \\
1 & 2 & - & - & $4(3)$ \\
1 & 1 & 1 & - & $5(4)$ \\
\hline
\end{tabular}

* Sites included are third-party owned (i.e. non-competing/independent firms) and excludes private exchanges. The sample comprises emarketplaces that are open to multiple buyers and suppliers and have at least one online trading function through which the e-marketplace itself does not buy or sell (Source: eMarket Services, 2007).

**Information obtained from individual e-marketplaces' 'terms and conditions', 'privacy statement', and 'about us' sections as well as other relevant information posted on the site. 


\section{References}

Abrams, L., (2000). Exchanges under Scrutiny, InfoWorld, (July 10).

Axelsson, B., \& Wynstra, F., (2002). Buying Business Services, John Wiley, Chichester.

Bailey, D., (2001). Antitrust Implications of B2Bs: Covisint - A Competitive Collaboration? [www.ftc.gov/opp/ecommerce/comments/baileycovisint.pdf].

Bakos, Y., (1991). A Strategic Analysis of Electronic Marketplaces, MIS Quarterly (September), 15, 295-310.

Bakos, Y., (1997). Reducing Buyer Search costs: Implications for Electronic Marketplaces, Management Science, 43(12).

Barratt, M., \& Rosdahl, K., (2002). Exploring business-to-business marketsites, European Journal of Purchasing and Supply Management, 8(2), 111-122.

Brunelli, M. A., (1999). What Buyers Want From Web Sites, Purchasing Online, (December 16) [www. manufacturing. net/ magazine/ purchasing].

Bush, D., \& Gelb, B. D., (2005). When Marketing Practices Raise Antitrust Concerns, MIT Sloan Management Review, 46(4), 73-81.

Czinkota, M. R., (2000). The Policy Gap in International Marketing, Journal of International Marketing, 8(1), 99-111.

Dajani, F. M., (2001). Beyond Covisint - Antitrust Scrutiny of B2B Exchanges, Journal of the Missouri Bar (July/August 2001).

Day, G. S., (2000). Managing Market Relationships, Journal of the Academy of Marketing Science, 28(1), 24-30.

de Boer L., Harink J., \& Heijboer, G., (2002). A conceptual model for assessing the impact of electronic procurement, European Journal of Purchasing and Supply Management, 8(1), 25-33.

Deeter-Schmelz, D. R., \& Norman Kennedy, K., (2002). An exploratory study of the Internet as an industrial communication tool: Examining buyers' perceptions, Industrial Marketing Management, 31(2), 145-154.

Djelic. M. L. (2002). Does Europe mean Americanization? The Case of Competition, Competition and Change, 6(3), 223-250. 
Department of Justice/Federal Trade Commission (1996). Statements of antitrust enforcement policy in health care [http://www.ftc.gov/reports/hlth3s.pdf].

Dou, W., \& Chou, D. C., (2002). A structural analysis of business-to-business digital markets, Industrial Marketing Management, 31(2), 165-176.

Edwards, C. D., (1950). Trends in the enforcement of the antimonopoly laws, Journal of Marketing, 15(5), 657- 665.

eMarket Services (2007). www.emarketservices.com.

Eng, T-Y., (2004). The role of e-marketplaces in supply chain management, Industrial Marketing Management, 33(2), 97-105.

Engle, N. H. (1936). Implications of the Robinson-Patman Act for marketing, Journal of Marketing, 1(2), 75-81.

Federal Trade Commission (2000). Entering the $21^{\text {st }}$ century: Competition policy in the world of B2B electronic marketplaces, [www.ftc.gov/os/2000/10/b2breport.pdf].

Federal Trade Commission/Department of Justice (April, 2000). Antitrust guidelines for collaborations among competitors, [www.ftc.gov/os/2000/04/ftcdojguidelines.pdf].

Fontenot, R. J., \& Hyman, M. R., (2004). The antitrust implications of relationship marketing, Journal of Business Research, 57(11), 12111221.

Forrester Research (2000). To flourish, emarkets must honor confidentiality, address security, and resolve liability issues, Online Report [www.forrester.com].

Garcia-Dastugue, S. J., \& Lambert, D. M., (2003). Internet-enabled coordination in the supply chain, Industrial Marketing Management, 32(3), 251-263.

Goldsby, T. J., \& Eckert, J. A., (2003). Electronic transportation marketplaces: a transaction cost perspective, Industrial Marketing Management, 32(3), 187-198.

Grewal, R., Comer, J. M., \& Mehta, R., (2001). An investigation into the antecedents of organizational participation in business-to-business electronic markets, Journal of Marketing, 65(July), 17-33. 
Gundlach, G. T. \& J. M. Phillips, (2002). Marketing in Antitrust: Contributions and Challenges, Journal of Public Policy and Marketing, 21(2), 250253.

Hannon, D., (2003). Suppliers: friend or foe? Traditional supplier management strategies begin to blur in the automotive industry, Purchasing, (February 6).

Hannon, D., (2004). SupplyOn takes on North American market, Purchasing, (August 17).

Hicks, M., (2000). Policing antitrust without government. eWeek, 17 (July 17), 50.

Horton, T. J., \& Schmitz, S., (2002). The lessons of Covisint: Regulating B2Bs under European and American Competition Laws, Wayne Law Review, 2002, 47(4), 1231-1300.

Howard, M., Vidgen, R., \& Powell, P., (2005). Automotive e-hubs: Exploring motivations and barriers to collaboration and interaction, Journal of Strategic Information Systems, 15(1), 51-75.

IBM, i2 \& Ariba (2000). E-marketplaces changing the way we do business, [www.ibm-i2-ariba.com].

Institute for Supply Management (2005). Principles and Standards of Ethical Supply Management Conduct, [http://www.napm.org/].

Jap, S., \& Mohr, J., (2002). Leveraging Internet technologies in B2B relationships. California Management Review 44(4): 24-38.

Kalyanam, K. S., \& Mclntyre, S., (2002). The e-marketing mix: A contribution of the e-tailing wars, Journal of the Academy of Marketing Science, 30(4), 487-499.

Kaplan, S., \& Sawhney, M., (2000). E-Hubs: The New B2B Marketplaces, Harvard Business Review, (May/June), pp.97-103.

Kehng, C. B., \& Al-Hawamdeh. S., (2002). The adoption of electronic procurement in Singapore, Electronic Commerce Research, 2(1/2), 6173.

Kirkwood, J. B., (2004). Buyer power and exclusionary conduct: Should Brooke Group set the standards for buyer-induced price discrimination and predatory bidding? Antitrust Law Journal, 72(2), 625-668. 
Klein, L. R., \& Quelch, J. A., (1997). Business-to-business market making on the Internet, International Marketing Review, 14(5), 345-361.

Klein, J. I., (1999). Antitrust enforcement and the consumer, US Department of Justice, Washington (DC) [http://usdoj.gov/atr/public/div_stats/1638.htm].

Koch, C., (2002a). The future of e-commerce: Motorcity Shakeup, Darwin Newsletter, (January), [http://www.darwinmag.com].

Koch, C., (2002b). Covisint's last chance, December 1, ClO Magazine, [http://www.cio.com/archive/120102/ecomm.html].

Labaton, S., (2000). As competition heats up, so does the threat of collusion. New York Times, (Oct 22), 25.

Laflamme, E. M., \& Biggio, C. E., (2001). Applying antitrust law to B2B marketplaces, Start-up \& Emerging Companies Strategist, [http://www.akingump.com/publication].

Lancioni, R. A., Schau, H. J., \& Smith, M. F., (2003a). Internet impacts on supply chain management, Industrial Marketing Management, 32(3), 173-175.

Lancioni, R. A., Smith, M. F., \& Schau, H. J., (2003b). Strategic Internet application trends in supply chain management, Industrial Marketing Management, 32(3), 211-217.

Lichtenthal, J. D., \& Eliaz, S., (2003). Internet integration in business marketing tactics, Industrial Marketing Management, 32(3), 3-13.

Lancastre, A., Lages, L. F., (2006). The relationship between buyer and a B2B e-marketplace: Cooperation determinants in an electronic market context, Industrial Marketing Management, 35(6), 774-789.

LeClair, D. T., (2000). Marketing planning and the policy environment in the European Union, International Marketing Review, 17(3), 193-215.

McBride, S., (2005). E-marketplaces find their niche, Computerworld, (11/02/2005) [http://www.computerworld.com.au].

McKenna, R. (1997). Real time: Preparing for the age of the never satisfied customer, Harvard Business School Press: Boston.

McNair, M. P. (1938).Fair trade legislation and the retailer, Journal of Marketing, 2(4), 295-300. 
Min, H., \& Galle, W., (1999). Electronic commerce usage in business-tobusiness purchasing, International Journal of Operations \& Production Management, 19(9), 909-921.

Nystrom, P. H., (1936). Legislative trends of interest to students of marketing, Journal of Marketing, 1(2), 154-155.

Ordanini, A., Micelli, S., \& Di Maria, E., (2004). Failure and success of B-to-B exchange business models: A contingent analysis of their performance, European Management Journal, 22, 281-289.

Petty, R. D., (2005). Societal Regulation of the Marketing Function: Does the Patchwork Create a Quilt, Journal of Public Policy and Marketing, 24(1), 63-74.

Petty R. D., (1999). Editors Introduction: The what and why of marketing law, American Business Law Journal, 36, 239-254.

Presutti, Jr., W. D., (2003). Supply management and e-procurement: creating value added in the supply chain, Industrial Marketing Management, 32(3), 219-226.

Sharma, A., (2002). Trends in Internet-based business-to-business marketing, Industrial Marketing Management, 31(2), 77-84.

Shapiro, C., \& Varian, H. R., (1999). Information Rules: A Strategic Guide to the Network Economy, Harvard Business School Press: Boston.

Skjøtt-Larsen, T., Kotzab, H., \& Grieger, M., (2003). Electronic marketplaces and supply chain relationships, Industrial Marketing Management, 32(3), 199-210.

Sterling, H., (2001). Mismatch? Is your B2B collaboration risking an antitrust suit? ClO Magazine, (June 15) [http://www.cio.com/archive/061501/fine.html].

The Economist (2000). Seller beware, (March 4), pp.61-62.

Tyagi, R. K., (2001). Why do suppliers charge larger buyers lower prices? Journal of Industrial Economics, 49(1), 45-61.

Varadarajan, P. R., \& Yadav, M. S., (2002). Marketing strategy and the Internet: An organizing framework, Journal of the Academy of Marketing Science, 30(4), 296-312.

Werden, G. J. (2002). Assigning Market Shares, Antitrust Law Journal, 70, 67104. 
Zhu, K., (2004). Information transparency in electronic marketplaces: why data transparency may hinder the adoption of B2B exchanges, Electronic Markets, 12(2), 92-99. 